Effect of Endurance Training on Central/Peripheral Fatigue and Postural Control Following High Intensity

Dynamic Exercise 


\section{Effect of Endurance Training on Central/Peripheral Fatigue and Postural Control Following High Intensity \\ Dynamic Exercise}

PhD Thesis by

Hamidollah Hassanlouei

Center for Sensory-Motor Interaction, Department of Health Science and Technology, Aalborg University, Denmark

Aalborg 
ISBN 978-87-93237-18-6 (paperback)

ISBN 978-87-93102-57-6 (e-book)

Published, sold and distributed by:

River Publishers

Niels Jernes Vej 10

9220 Aalborg Ø

Denmark

Tel.: +45369953197

www.riverpublishers.com

Copyright for this work belongs to the author, River Publishers have the sole right to distribute this work commercially.

All rights reserved (c) 2014 Hamidollah Hassanlouei.

No part of this work may be reproduced, stored in a retrieval system, or transmitted in any form or by any means, electronic, mechanical, photocopying, microfilming, recording or otherwise, without prior written permission from the Publisher. 



\section{Contents}

Preface vii

Abstract ix

Dansk Sammenfatning xi

Abbreviations $\quad$ xiii

Introduction 1

Muscle Fatigue . . . . . . . . . . . . . . . . . 2

Postural Control ...................... 3

Sensory - Motor Control of Skeletal Muscle . . . . . . . . 4

Skeletal and Muscle System _. . . . . . . . . . . . 4

Postural Control and Muscle Fatigue . . . . . . . . . . . 5

Muscle Fatigue and Related Injury . . . . . . . . . . . . . 5

Endurance Training and Adaptation . . . . . . . . . . 6

Training Adaptations in the Behavior of Human

Motor Units . . . . . . . . . . . . . . . . . . 8

Methods 9

Electromyography $($ Studies 1 and 2) . . . . . . . . . . 9

EMG During Sustained Contractions (Studies 3 and 4) . . . . . 10

Maximal Voluntary Force (Studies 1-4) . . . . . . . . . . 10

Electrical Stimulation (Study 4) f . . . . . . . . . . . 11

Center of Pressure $($ Study 3$) \ldots \ldots \ldots 1$

Subjects ......................... 12

Summary of the Studies $\quad 13$

Study I . . . . . . . . . . . . . . . . . . . . . . . . . . . . 13

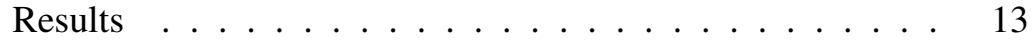

Discussion . . . . . . . . . . . . . . 13

Study II . . . . . . . . . . . . . . . . . . . . . . 15

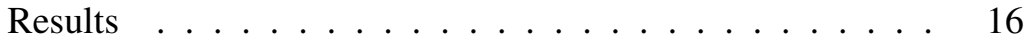

Discussion . . . . . . . . . . . . . 16 
vi Contents

Study III . . . . . . . . . . . . . . . . . . . . . . . 18

Results .................. 18

Discussion . . . . . . . . . . . . . . . . 19

Study IV . . . . . . . . . . . . . . . . . . 20

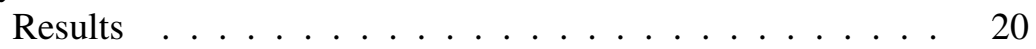

Discussion .................... 20

General Discussion and Conclusions $\quad 25$

$\begin{array}{ll}\text { References } & 27\end{array}$

About the Author 33 


\section{Preface}

This thesis would not have been possible without the support and encouragement of some people that I would like to mention here.

I specially want to thank my supervisors, Professor Deborah Falla and Professor Uwe Kersting whose encouragement, supervision and support from an idea to the final stage enabled me to develop and understanding of this topic.

I would like to express my gratitude to Professor Lars Arendt-Nielsen, who gave me the opportunity to carry out this research at Aalborg University and for his supervision, continuous moral and financial support, which was essential in completion of this thesis.

I would also like to thank all my colleagues for providing friendly, inspiring and competitive research environment. Particularly, I thank Anderson Oliveira and Shinichiro Shiozawa for their help during data collection. I also appreciate the patience and cooperation of all volunteers who participated in the experiments of the current $\mathrm{PhD}$ study.

To my lovely family who supported me, encouraged me and prayed for me 



\section{Abstract}

The objective of this thesis was to investigate the effect of musculoskeletal fatigue on postural control and the effect of an endurance training intervention on central and peripheral components of fatigue. The muscles around the knee play an important role in explosive and powerful performance of the leg during daily life and sporting activities. However, fatigue- induced impairments in muscle function may reduce the ability of the muscles around the knee to stabilize the knee joint. This may expose structures of the knee to abnormal loading during exercise. Training has been extensively shown to lead to resistance to fatigue however the effects of endurance training on postural control as well as central and peripheral components of exercise induced fatigue is unknown.

In this thesis, four studies were performed. First, the effects of eccentric exercise and delayed onset muscle soreness of the knee muscle on postural control were investigated in healthy subjects. In this study muscle activation around the knee were examined. In a second study, the effects of dynamic fatiguing exercise on postural control were investigated and muscle activation responses following high intensity dynamic exercise were investigated. In third study, the effects of 6 weeks progressive endurance training on postural control following fatiguing exercise were examined. In the fourth and final study, the effects of training on central and peripheral components of fatigue following high intensity dynamic exercise were investigated.

The results showed lower electromyography (EMG) amplitude and delayed EMG onset following skeletal muscle fatigue induced by eccentric and dynamic exercise. However, following 6 weeks endurance training subjects increased their resistance to fatigue, i.e., were able to sustain a high power output, showed increased knee maximum muscle force and smaller decrement in force following exercise, and a smaller reduction in muscle fiber conduction velocity during a sustained contraction. Moreover following training, subjects improved postural stability during unexpected perturbations in the presence of fatigue. Training induced adaptations were shown to occur at both peripheral and central components of the nervous system. 
This thesis provided insight into the contribution of fatigue components to the regulation of balance after unexpected perturbations. Moreover, it was shown how endurance training affected resistance to fatigue and improved balance regulation in the fatigued state. These findings will assist in the development of specific training programs to improve resistance to fatigue and allow for an improved stability regulation following unexpected perturbations. 


\section{Dansk Sammenfatning}

Formålet med denne afhandling var at undersøge effekten af muskuloskeletal træthed på holdningskontrollen og effekten af en udholdenhedstræningsintervention på centrale og perifere komponenter af træthed. Musklerne omkring knæet spiller en vigtig rolle, når benet skal levere eksplosive og kraftfulde bevægelser både i dagligdagen og ved idrætsudøvelse. Dog kan træthedsinducerede svækkelser i muskelfunktionen reducere evnen til at stabilisere knæleddet i musklerne omkring knæet. Dette kan betyde, at strukturerne i knæet udsættes for unormal belastning ved motion. Det er påvist, at træning fører til modstand over for træthed, dog kendes effekten af udholdenhedstræning på holdningskontrollen ikke. Ligeledes kendes centrale og perifere komponenter af induceret træthed ikke.

Afhandlingen er baseret på fire studier. Det første studie omhandlede effekten af excentriske $\varnothing$ velser og forsinket muskel $\varnothing$ mhed (delayed onset muscle soreness) i knæmusklen på holdningskontrollen hos raske forsøgspersoner. Studiet undersøgte muskelaktiveringen omkring knæet. Det andet studie undersøgte effekten af dynamiske udtrætningsøvelser på holdningskontrollen samt muskelaktiveringsresponser efter dynamisk træning med høj intensitet. Det tredje studie unders $\varnothing$ gte effekten af seks ugers progressiv udholdenhedstræning på holdningskontrollen efter udtrættende træning. Det fjerde og sidste studie omhandlede effekten af træning på centrale og perifere komponenter af træthed efter dynamisk træning med høj intensitet.

Resultaterne viste en lavere elektromyografi (EMG) amplitude og forsinket EMG-frembrud efter skeletmuskeltræthed induceret ved hjælp af excentrisk og dynamisk træning. Men efter 6 ugers udholdenhedstræning udviste forsøgspersonerne forøget modstandskraft til træthed, dvs. at de var i stand til at opretholde en høj kraftydelse, udviste forøget maksimal muskelkraft i knæet, mindre reduktion i kraften efter træning samt en mindre reduktion i muskelfiberledningshastigheden under en vedvarende muskelsammentrækning. Endvidere udviste fors $\emptyset$ gspersonerne forbedret holdningsstabilitet under uventede perturbationer under tilstedeværelse af træthed. Træningsinducerede tilpasninger fremkom i både perifere og centrale komponenter i nervesystemet. 


\section{xii Dansk Sammenfatning}

Afhandlingen har givet indsigt $\mathrm{i}$ træthedskomponenternes bidrag til regulering af balancen efter uventede perturbationer. Endvidere har afhandlingen vist, hvordan udholdenhedstræning påvirker modstand over for træthed og giver forbedret balanceregulering i træthedstilstand. Disse resultater kan bidrage til udviklingen af specifikke træningsprogrammer, som skal forbedre modstanden over for træthed og skabe en forbedret stabilitetsregulering efter uventede perturbationer. 


\section{Abbreviations}

$\begin{array}{ll}\text { ARV } & \text { Average rectified value } \\ \text { BF } & \text { Biceps femoris } \\ \mathrm{Ca}^{+} & \text {Calcium } \\ \mathrm{CAR}^{+} & \text {Central activation ratio } \\ \mathrm{Cl}^{-} & \text {Chloride } \\ \mathrm{COP} & \text { Center of pressure } \\ \text { DOMS } & \text { Delayed onset muscle soreness } \\ \mathrm{EC} & \text { Excitation-contraction } \\ \mathrm{EMG} & \text { Electromyography } \\ \mathrm{H}^{+} & \text {Hydrogen } \\ \mathrm{K}^{+} & \text {Potassium } \\ \mathrm{MU} & \text { Motor unit } \\ \mathrm{MFCV} & \text { Muscle fiber conduction velocity } \\ \mathrm{MVC} & \text { Maximal voluntary contraction } \\ \mathrm{Na}+ & \text { Sodium } \\ \mathrm{Pi} & \text { Inorganic phosphate } \\ \mathrm{RF} & \text { Rectus femoris } \\ \mathrm{ST} & \text { Semitendinosus } \\ \text { VL } & \text { Vastus lateralis } \\ \text { VM } & \text { Vastus medialis }\end{array}$





\section{Introduction}

Functional joint stabilization during daily life and sporting activities is routinely achieved as the body collects visual information, proprioceptive information from articular and musculotendinous receptors, and vestibular information from the vestibules and semicircular canals of the ears. Once gathered, this information is processed by the central nervous system and results in the maintenance of posture and balance, the conscious appreciation of joint motion and position sense, and protective spinal-mediated reflexes.

Skeletal muscle fatigue is an inevitable part of any exercise and is associated with impairments in joint proprioception, joint position sense and joint laxity (Barrack et al., 1983). Several studies confirm that muscle fatigue increases postural sway and impairs the response to external perturbations (Gribble et al., 2004; Surenkok et al., 2006; Villuirme, 2007). The factors that could potentially alter balance performance after fatigue include both central and peripheral components of fatigue. During the fatiguing state the ligamentous structure around the joint may undergo some increase in laxity during exercise, thereby placing athletes at risk for injury (Skiner et al., 1984; Sakai et al., 1992).Various types of training have also been shown to enhance postural control during static or dynamic perturbations (Myer et al., 2006a, 2006b). However such studies have been conducted on individuals in an unfatigued resting state.

Endurance training results in numerous adaptations within the skeletal muscle and has been dominantly used to increase resistance to fatigue. Thus there is no knowledge on whether endurance training would counteract the increased postural sway observed during perturbations in a fatigued state. Therefore the general aim of this thesis is to investigate the effects of eccentric and dynamic exercise induced fatigue of the knee muscles on postural control. Moreover, central/peripheral components of the dynamic exercise induced fatigue and the effects of endurance training on these components and postural control will be analyzed. 


\section{Introduction}

\section{Muscle Fatigue}

Human skeletal muscle fatigue, defined as a loss of maximum force-generating capacity, may develop for a variety of reasons. Failure of force production may occur at the various sites along the pathway from the central nervous system through to the intramuscular contractile machinery. The typical strategy used to study fatigue has been to determine whether the mechanism responsible for fatigue is located in the exercising muscle (i.e. peripheral fatigue), or in the nervous system (i.e. central fatigue).

Central fatigue is defined as a reduction in neural drive or motor command to the muscle resulting in a decline in force production or tension development (Gandevia, 2001). The central fatigue model posits that the reduction in power output during prolonged exercise leading to the cessation of exercise is not caused by limiting physiological processes in any of the peripheral organs including the active skeletal muscles. Rather, the fatigue related reductions in skeletal muscle power output are caused by altered efferent command. Another hypothesis for central fatigue is that changes in the concentration of certain brain neurotransmitters cause fatigue. For example, serotonin (5-hydroxytryptamine) concentrations increase during exercise as fatigue develops. (Blomstrand et al., 1991; Wilson et al., 1992) Similarly, dopamine (Bailey et al., 1993; Ziv et al., 1998) and acetylcholine (Conlay et al., 1994) concentrations decline, while concentrations of cytokines (Smith et al., 2000) and ammonia (Guezennec et al., 1998) increase. Inoue et al (Inoue et al., 1999) propose that the concentrations of chemicals such as actively transforming growth factor $b$ increase in the cerebrospinal fluid during exercise and may also cause fatigue.

On the other hand, peripheral fatigue is defined as a decrease in the force generation capacity of the skeletal muscle because of action potential failure, or excitation-contraction coupling failure, or impairment of cross-bridge cycling, in the presence of unchanged or increasing neural drive (Hakkinen et al., 1983; Taylor et al., 1997) (Figure 1).

These metabolic changes associated with fatigue include the relative contributions of lactate level increases, $\mathrm{pH}$ decrease and associated proton accumulation, ATP and creatine phosphate depletion, ADP, inosine monophosphate and inorganic phosphate accumulation, skeletal muscle $\mathrm{Na}+/ \mathrm{K}+$ ATPase pump changes, and sarcolemmal, T-tubule and sarcoplasmic reticulum functional changes, described as excitation/contraction coupling failure (Fitts, 1994). Both central/peripheral mechanisms of fatigue are influenced by the characteristics of the task being performed (i.e. type 


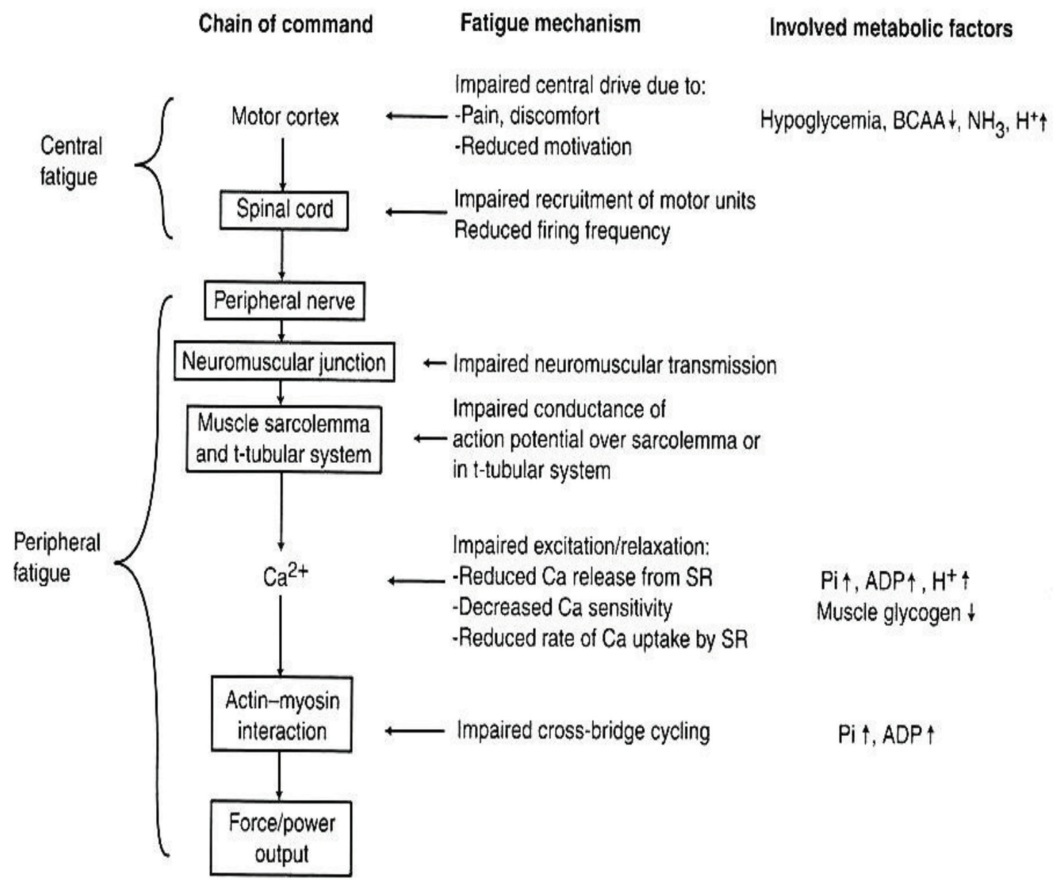

Figure 1 Schematic of the chain of the command for muscle contraction and lit of possible mechanisms causing central and peripheral fatigue. $\mathrm{ADP}=$ adenosine diphosphate; $\mathrm{BCAA}=$ branch-chained amino acids; $\mathrm{NH}_{3}=$ ammonia (sum of $\mathrm{NH}_{3}$ and $\mathrm{NH}_{4}{ }^{+}$); $\mathrm{Pi}=$ inorganic phosphate; $\mathrm{SR}=$ sarcoplasmic reticulum. Adopted from Exercise Metabolism- Human kinetics - 2006

and duration of the exercise, speed and duration of the muscle contraction (Enoka, 1992). Moreover, it has been demonstrated that peripheral fatigue can slow the propagation of the activation down the t-tubules, and therefore delay the activation of the contractile elements that generate force and power in response to the perturbation (Fitts, 1996).

\section{Postural Control}

'Balance' can be described as the ability to maintain the body's position over its base of support (Berg et al., 1989, Spirduso, 1995). Balance, or "a state of equilibrium" has been divided into static balance and dynamic balance, depending on whether the base is stationary or moving (Becker et al. 1986). The balancing of the human body is a complicated process, which 


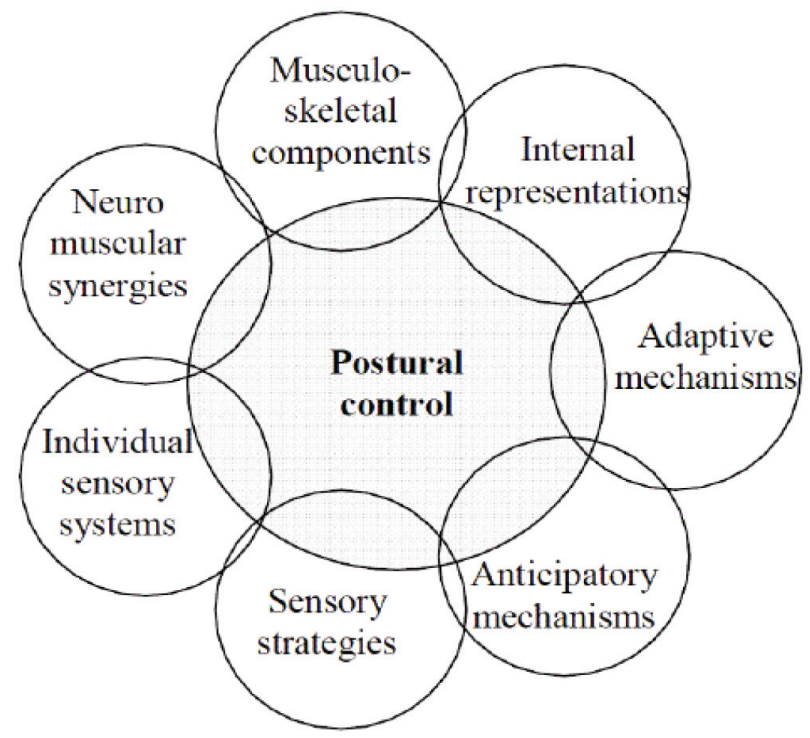

Figure 2 Model illustrating the main components of the premises for postural control and their interaction (adapted from Shumway-Cook and Woollacott, 2001)

demands coordination of the sensory, musculoskeletal and central nervous systems. (Figure 2)

\section{Sensory - Motor Control of Skeletal Muscle}

Sensory systems consisting of visual, vestibular and somatosensory components coordinate the information regarding the body's position relative to gravity and the environment and positions of body parts in relation to each other. There are some essential inputs for postural control during stance produced by proprioception. First, stimuli from visual, vestibular and somatosensory sources are required to contribute information about the body's position in space. Subsequently, coordinated responses to stimuli must be transmitted to the appropriate muscles to produce corrective movements in certain joints to balance a standing position.

\section{Skeletal and Muscle System}

Postural control requires coordinated muscle activation (Johansson and Magnusson 1991), for example, to produce adequate muscular contractions (Era et al., 1996). Although the calf musculature is activated first to provide 
postural control during body movements (Nashner, 1983), the co-activation of certain "prime postural muscles", such as the neck muscles, the hamstring musculature, the soleus and supraspinalis muscles, occurs in this order (Nashner, 1983; Johansson and Magnusson, 1991). However, in order to balance the body position, different muscles participate with different latency times (Nashner, 1983). As muscles are stretched, the proprioceptive receptors within the muscle and tendon signal the change in muscle length to the central mechanism provides the needed segmental movement and position information to the motor control system (Prochazka and Wand 1980; Spirduso, 1995).

\section{Postural Control and Muscle Fatigue}

Postural control is a key component of successfully completing both activities of daily living and participating in athletic events. Maintenance of posture is reliant on input from the visual, vestibular, and somatosensory systems. The somatosensory system receives input from articular, cutaneous, and musculotendinous receptors, including muscle spindles and Golgi tendon organs, that send afferent signals regarding changes in length and tension. It is theorized that muscle fatigue may impair the proprioceptive and kinesthetic properties of joints by increasing the threshold of muscle spindle discharge, disrupting afferent feedback, and subsequently altering conscious joint awareness (Miura et al., 2004). Therefore, altered somatosensory input due to fatigue could result in deficits in neuromuscular control as represented through deficits in postural control (Gribble and Hertel, 2004). Submaximal contractions maintained until exhaustion create alterations of muscle properties including the action potential, extracellular and intracellular ions and many intracellular metabolites (Allen et al., 2008). These alterations decrease muscular excitability and conduction velocity of afferent inputs undergoes a deceleration, which induces a decrease of the propagation velocity of the motor output (Broman et al., 1985) required for maintaining postural balance. Decrease in $\mathrm{pH}$ related to the dissociation of lactic acid produced during exercise into lactate and hydrogen $\left(\mathrm{H}^{+}\right)$affects postural control (Surenkok et al., 2008).

\section{Muscle Fatigue and Related Injury}

Postural control is a quantifiable measure of neuromuscular control which plays an important role in dynamic joint stability and protecting the body from injury. Wojtys et al., (1996) found that fatigue to the quadriceps and hamstrings 


\section{Introduction}

of healthy individuals led to increased reaction times of those muscle groups in response to imposed anterior translation at the knee. An explanation for the relationship between fatigue and altered neuromuscular control is that slowed conduction of afferent signals from the fatigue altered state of the muscle will lead to slowed propagation of efferent signals, thereby affecting the ability to create compensatory movement effectively (Rozzi et al., 2000).

Though largely anecdotal, studies have reported that more injuries tend to occur near the end of a sporting event, when athletes may experience muscle fatigue (Feagin et al., 1987; Hawkins and Fuller, 1999). These observations suggest that muscle fatigue may be a predisposing factor that contributes to lower extremity injuries. By altering the force producing capability of the muscles surrounding the joint, fatigue may contribute to injuries by exposing ligaments and other static restraints to excessive loads.

Moreover, Muscle fatigue has been shown to adversely alter joint proprioception (Miura., et al., 2004; Rozzi et al., 2000; Voight et al., 1996) and impair neuromuscular control in the lower extremities. Deterioration in proprioception as a result of fatigue may be a risk of knee ligamentous injury (Lattanzio et al., 1997; Skinner et al., 1986). Previous reports that the incidence of injury to skiers is higher in the afternoon (Tuggy et al., 2000) and that to football players is higher in the third quarter (Zempher, 1989) suggest that fatigue in athletes may produce a decline of knee proprioception and be one of the risk factors for knee ligament injuries.

In general different protocols have been used to induce fatigue in the knee muscles in order to study its effects on postural control. In some studies local load induced by isokinetic exercise in the laboratory is intended to produce local fatigue of the knee, which may cause dysfunction of muscle mechanoreceptors. Others have used general load, which more practically simulates sports activity in athletes, may produce not only local fatigue of the knee but also general fatigue, which may affect other mechanisms in the proprioceptional pathway. In general, the results from these investigations have demonstrated an increase in postural sway as a function of muscular fatigue.

\section{Endurance Training and Adaptation}

Endurance can be defined as the capacity to sustain a given velocity or power output for the longest possible time. The performance of repeated bouts of exercise over a period of time causes numerous physiological changes that result in improved performance in that exercise activity. The magnitude of the 
training response depends on the duration of the exercise bouts, their intensity and the frequency with which they are performed (Wenger and Bell, 1986) along with the initial training status, genetic potential, age and gender of the individual.

Endurance training causes adaptations in the pulmonary, cardiovascular and neuromuscular systems that improve the delivery of oxygen from the atmospheric air to the mitochondria and enhance the control of metabolism within the muscle cells. Within skeletal muscle Endurance training results in numerous adaptations that may be significant for exercise performance, including increases in sodium-potassium pump concentration (Green et al., 1993) lactate transport capacity (Pilegaard et al., 1994; McCullagh et al., 1996) and possibly myoglobin concentration (Harms and Hickson, 1983). Endurance training also results in a marked increase in the oxidative capacity of skeletal muscle. This is due to an increase in the size and the number of mitochondria per unit area and an increase in the concentration of the enzymes of the Krebs cycle, electron transport chain and malate-aspartate shuttle (Schantz et al., 1986; Spina., 1996).

Endurance training is also associated with a reduction in the degree of lactacidaemia for any given absolute or relative exercise intensity. This causes the power output or running speed corresponding to arbitrary 'blood lactate reference values' such as $4 \mathrm{mmol} / \mathrm{L}$ blood lactate to increase following a period of endurance training. The reduction in blood lactate for the same absolute and relative exercise intensities following endurance training may result from a reduction in the rate of lactate production (possibly consequent to a lower rate of muscle glycogen utilization or to speeded oxygen uptake kinetics that may increase initial $\mathrm{O}_{2}$ availability/utilization (Favier et al., 1986) or from an increase in the ability to exchange and remove lactate from the blood (Bonen et al., 1997).

Endurance training also results in a marked increase in the oxidative capacity of skeletal muscle. This is due to an increase in the size and the number of mitochondria per unit area and an increase in the concentration of the enzymes of the Krebs cycle, electron transport chain and malate-aspartate shuttle (Schantz et al., 1986; Spina, 1996). The greater capacity of the Krebs cycle to accept pyruvate following training may be important in reducing the production of lactate by mass action at the onset of exercise and during high intensity exercise (Graham and Saltin, 1986). However, the greater capillarity of trained muscle also allows for a greater uptake of free fatty acids from the blood and the increased activity of the enzymes involved in lipid metabolism increase the capacity for mitochondrial B-oxidation (Kiens et al., 1993). 


\section{Training Adaptations in the Behavior of Human Motor Units}

Beaumont and Gardiner (Beaumont and Gradiner, 2003) reported that endurance training in rats changed the biophysical properties of motor neurons, which resulted in a more hyperpolarized resting membrane potential, increased threshold for spike initiation, and faster rise times for antidromic spikes. These adaptations, which likely reflect alterations in ionic conductances of motor neurons, can modify the recruitment thresholds and discharge patterns of the neurons. In a cross-sectional study, Lattier et al (Lattier et al., 2003) compared the explosive and isometric strength of endurance-trained, powertrained and sedentary subjects. The authors found that endurance-trained athletes had higher maximal isometric force and maximal voluntary activation of knee extensors than sedentary subjects. The authors suggested that these results demonstrate neural adaptations (e.g. maximal voluntary activation), due to any given type of training, regardless of the intensity of the training stimulus. It is also assumed that untrained adults cannot fully activate their motor units or cannot activate them at an optimal firing rate during maximal voluntary contraction (De Luca et al., 1982). Although a small number of studies have looked at the effect of endurance training on the neuromuscular system, none of those studies have investigated the effect of endurance training on the rate of muscle activation.

Changes in excitation-contraction coupling and contractile properties of the muscle fibers, neural adaptation (increased MU activity, improved MU synchronization), are suggested as possible mechanisms for those changes (Paasuke et al., 1999). However, some studies have reported that muscle strength in athletes, even endurance-trained, is greater than non-athletes (Lattier et al., 2003). Another possible explanation for the greater maximal strength displayed by athletes is a training-induced reduction in co-activation (Lattier et al., 2003; De Luca et al., 1982; Carolan and Cafarelli, 1992). 


\section{Methods}

The methods of the four studies of this thesis are described in the following.

\section{Electromyography (Studies 1 and 2)}

Following skin preparation, pairs of circular $\mathrm{Ag}-\mathrm{AgCl}$ surface electrodes (Ambu Neuroline, conductive area $28 \mathrm{~mm}^{2}$ ) were placed in bipolar configuration (inter electrode distance 2-cm) over the rectus femoris (RF), biceps femoris (BF) and semitendinosus (ST) muscles of the right limb. Electrodes were placed over the RF at $10 \%$ of the distance between the superior border of the patella and anterior superior iliac spine (Hedayatpour et al., 2011). The position of electrodes on the hamstring muscle was determined by palpation of the most distal portion of the medial (biceps femoris) and lateral (semitendinosus) belly of the hamstrings during light isometric contractions with the subject in a prone position. In addition, adhesive linear arrays of eight equi-spaced electrodes (bar electrodes $5 \mathrm{~mm}$ long, $1 \mathrm{~mm}$ diameter, and $5 \mathrm{~mm}$ inter-electrode distance) were used to detect surface EMG signals from the right vastus medialis (VM) and vastus lateralis (VL) muscles. The arrays were located between the most distal innervation zone and the distal tendon region of the VM and VL muscles. The innervation zone and tendon regions were non-invasively identified during preliminary test contractions using a dry array similar to the adhesive array used for recording, as previously described (Masuda et al., 1985). The orientation of the array was based on visual inspection of the surface EMG signals detected in the test contractions with the criterion of minimal variation of the evoked action potentials. The skin was lightly abraded in the location selected for array placement. To assure proper electrode-skin contact $20 \mu \mathrm{l}$ of conductive gel were inserted into the cavities of the adhesive electrode arrays. A reference electrode was placed around the right ankle. Surface EMG signals were amplified (EMG128, OT Bioelettronica, Torino, Italy, bandwidth $10-500 \mathrm{~Hz}$ ), sampled at $2048 \mathrm{~Hz}$, and stored after 12-bit A/D conversion. 


\section{EMG During Sustained Contractions (Studies 3 and 4)}

An adhesive linear array of eight equi-spaced electrodes (bar electrodes 5-mm long, 1-mm diameter, 5-mm inter-electrode distance) was used to detect surface EMG signals. The array was located between the most distal innervation zone and the distal tendon region of the vastus medialis and vastus medialis muscle. (Figure 3)

Innervation zone and tendon regions were non-invasively identified in a few preliminary test contractions with the use of a dry array similar to the adhesive array used for recording, as previously described (Masuda et al., 1985). The orientation of the array was based on visual inspection of the surface EMG signals detected in the test contractions with the criterion of minimal variation in the shape of the action potentials. The skin was lightly abraded in the location selected for array placement. To assure proper electrode-skin contact $20 \mu$ of conductive gel were inserted into the cavities of the adhesive electrode array. Surface EMG signals amplified (EMG16, OT Bioelettronica, Torino, Italy, bandwidth $10-500 \mathrm{~Hz}$ ), sampled at 2,048 Hz, and stored after 12-bit A/D conversion.

\section{Maximal Voluntary Force (Studies 1-4)}

Maximal voluntary isometric contractions (MVC) of knee extension and flexion were measured before and after the exercise protocol with a load cell strapped to the subject's ankle $5 \mathrm{~cm}$ above the malleoli. The subject was seated on an adjustable chair with the hip and knee in $90^{\circ}$ flexion and the ankle in a neutral position. Straps were applied around the subject's hips and chest. Visual feedback of the force produced was provided on a screen positioned $50 \mathrm{~cm}$ in front of the subject. The subject was asked to perform three maximal
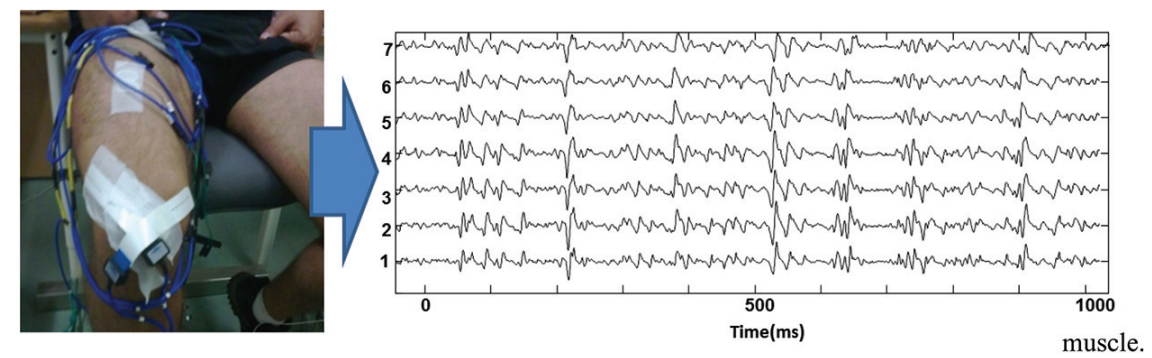

Figure 3 Representative recordings obtained during an isometric knee extension contraction from vastus medialis performed at $30 \%$ of the maximum voluntary force 
contractions in both knee extension and flexion ( $5 \mathrm{~s}$ in duration) in a random order with 2 min rest between each contraction. Verbal encouragement was provided to encourage maximal effort and the highest value of the three efforts was defined as the MVC.

\section{Electrical Stimulation (Study 4)}

The femoral nerve was stimulated using a monopolar cathode ball electrode (0.5-cm diameter) pressed into the femoral triangle by the experimenter. The site of stimulation was marked on the skin so that it could be exactly repeated between stimulations during the experiment. The anode was a rectangular electrode (PALS Flex 896230), $50 \mathrm{~cm} 2\left(10 \mathrm{~cm} \_5 \mathrm{~cm}\right)$, located in the gluteal fold opposite the cathode.

The intensity of the stimulation, which was a 1-ms rectangular pulse, was progressively increased until there was no further increase in the amplitude of the twitch (maximal intensity ranged from 45 to $75 \mathrm{~mA}$ ). Mmax was determined as the M-wave amplitude at the stimulus strength when the M-wave peak to peak amplitude no longer increased with increasing stimulus strength. Three stimuli at supra-maximal intensity (1.2 times the maximum M-wave stimulus intensity) were delivered. The voluntary activation level was estimated by expressing every increment in torque electrically evoked during the maximal isometric contractions. To quantify the central activation failure during each $\mathrm{MVC}$, the central activation ratio (CAR) was calculated according to the following equation (Kent-Braun, 1996):

$$
C A R=\frac{\text { MVC }}{\text { total force }} ;
$$

where total force $=$ stimulated + voluntary force. Thus, CAR $=1.0$ indicates complete voluntary activation of the muscle.

\section{Center of Pressure (Study 3)}

Measures of anterior-posterior $(F y)$ ground reaction forces were analyzed during full body perturbations performed before and after a high intensity exercise protocol (Figure 4). Subjects stood on a moveable platform which produced an $8 \mathrm{~cm}$ forward slide over $500 \mathrm{~ms}$ at random time points so that the subject could not anticipate the perturbation. Changes in the center of pressure were assessed from the onset of platform movement until $500 \mathrm{~ms}$ after completion of platform movement. 


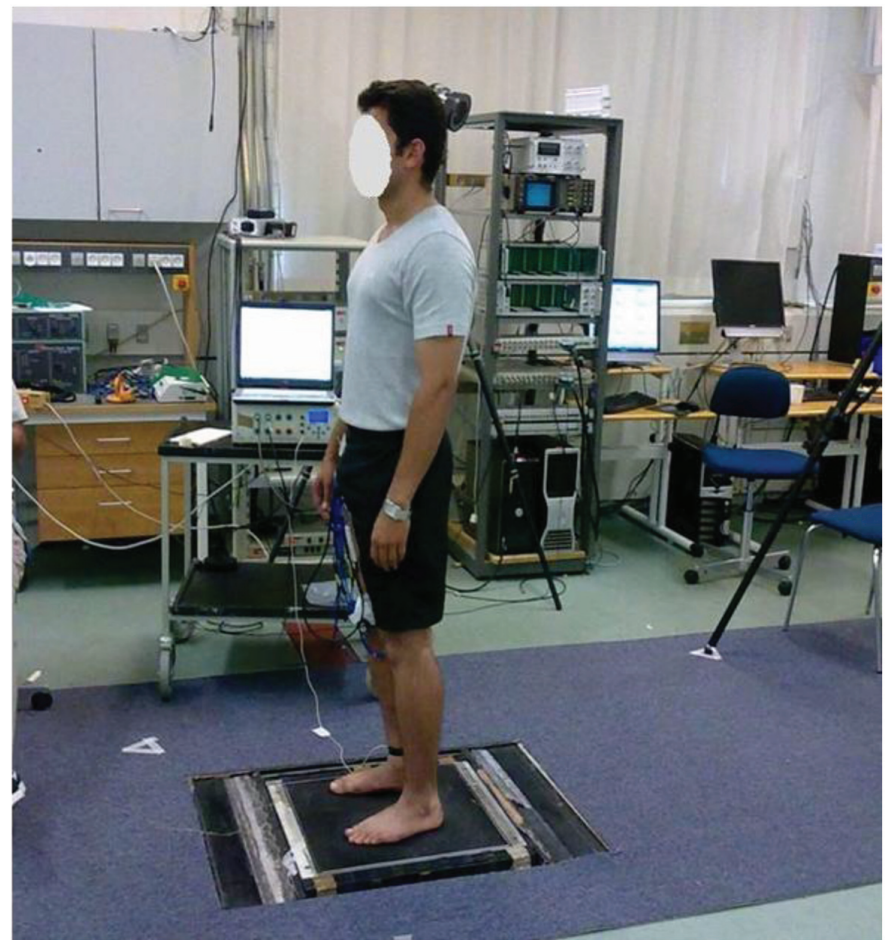

Figure 4 Subject position on force platform perturbations participants stood on a moveable platform during which 16 perturbations ( 8 repetitions of 2 perturbations type: $8 \mathrm{~cm}$ forward slides, $8 \mathrm{~cm}$ back ward slides) with varying inter-perturbation time intervals were performed over a period of $2-3 \mathrm{~min}$

\section{Subjects}

In total, 37 healthy sedentary men with no absence of any symptoms or special health condition that could interfere with test performance (e.g., cold, flu, fever and/or any discomfort) have volunteered in studies I-IIII. None of the subjects were involved in regular training. Table 1 shows the properties of subject pool for all studies.

Table 1 Subject pool properties in each one of the studies

\begin{tabular}{lllll}
\hline Subjects & Number & Age & Height & Weight \\
\hline Study I & 10 & $23.2(3.1)$ & $178(6)$ & $75.5(10)$ \\
Study II & 9 & $27(3)$ & $175(6)$ & $76.5(10.4)$ \\
Study III,IIII & 18 & $26.5(4.5)$ & $180(3)$ & $74.4(7.3)$ \\
\hline
\end{tabular}




\section{Summary of the Studies}

\section{Study I}

The first study investigated the effects of eccentric exercise and DOMS on delayed onset muscle soreness on response to postural perturbations. Bipolar surface EMG signals were recorded from 10 healthy men with seven pairs of electrodes located on the knee extensor muscles and knee flexor muscles of the right leg during rapid perturbations. Maximal voluntary contraction (MVC) force, subjective pain intensity ratings, and muscle circumference were measured before and after the exercise sessions. The exercise protocol was performed with a Kin-Com Isokinetic Dynamometer (Chattanooga, TN) and consisted of four bouts of 25 maximum voluntary eccentric knee extension contractions at a speed of $60^{\circ} \cdot \mathrm{s}^{-1}$ between 90- and 170- of knee extension, with 3 min of rest between each set.

\section{Results}

The present study demonstrated lower EMG amplitude of the DOMS-affected quadriceps muscle during rapid destabilizing perturbations immediately after and 24 and $48 \mathrm{~h}$ after eccentric exercise (Figure 5). Moreover, a greater reduction of muscle activity was observed during sustained contractions of the quadriceps muscle for the post exercise sessions with respect to the pre exercise session (Figure 6).

\section{Discussion}

The results suggest that eccentric contractions induce muscle fiber damage that is associated with delayed-onset muscle soreness and an impaired ability of the muscle to generate voluntary force. Moreover, eccentric exercise contributes to a reduced ability of the quadriceps to stabilize the knee joint during a destabilizing event, indicating that care should be taken to prevent knee injury when training programs include a large number of heavily loaded eccentric contractions. Pain and pathophysiological changes within the damaged muscle can delay or inhibit neuromuscular responses at the injured site, which is 


\section{Summary of the Studies}
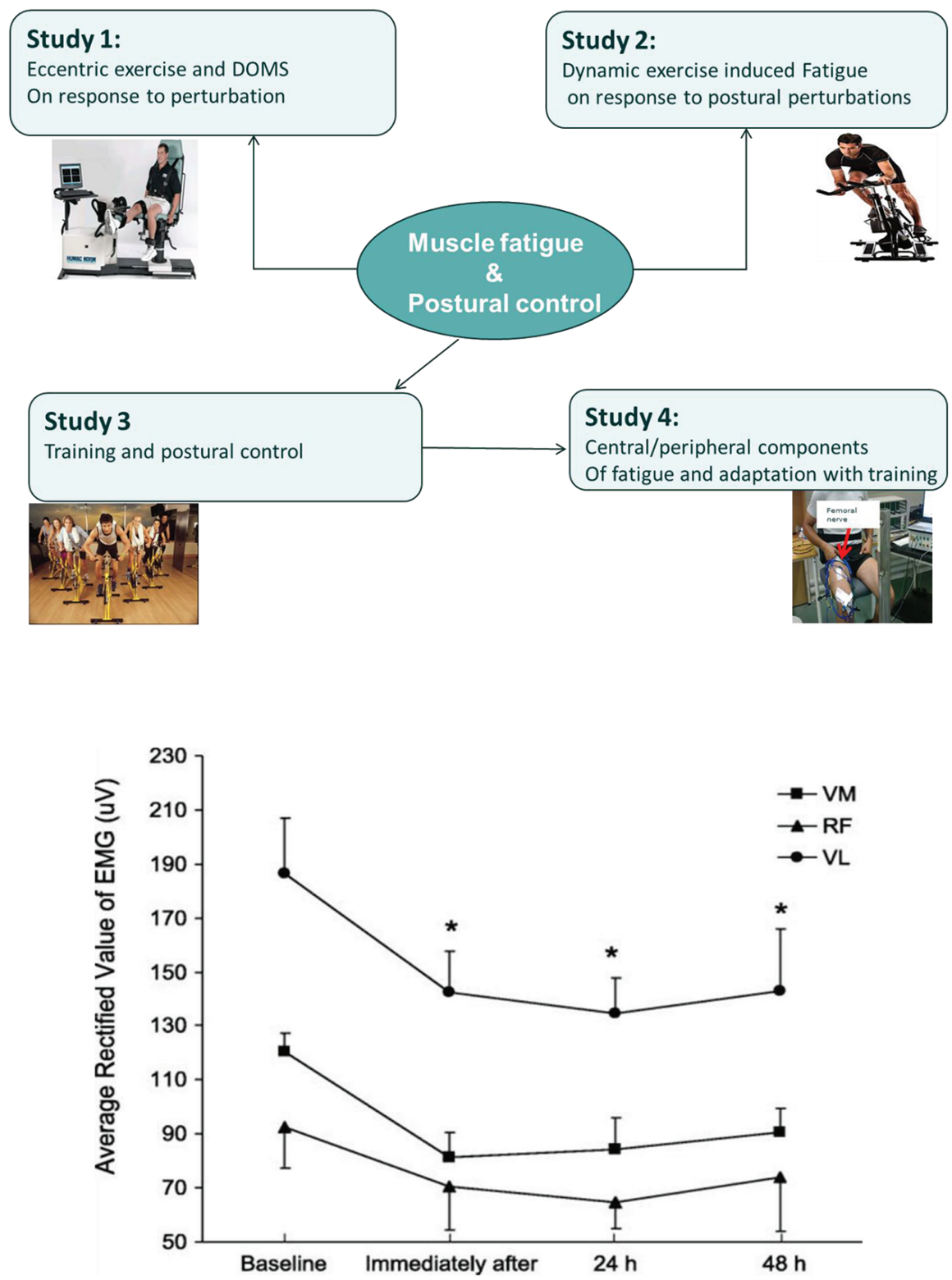

Figure 5 ARV of EMG (mean \pm SE, $n=10$ subjects) obtained froml75-ms epochs after the onset of plate movement (averaged for backward and forward directions) for the vastus medialis (VM), rectusfemoris (RF), and vastus lateralis (VL) muscle, recorded before the eccentric exercise (baseline), immediately after, and 24 and $48 \mathrm{~h}$ after eccentric exercise; $* \mathrm{P}<0.05$. 


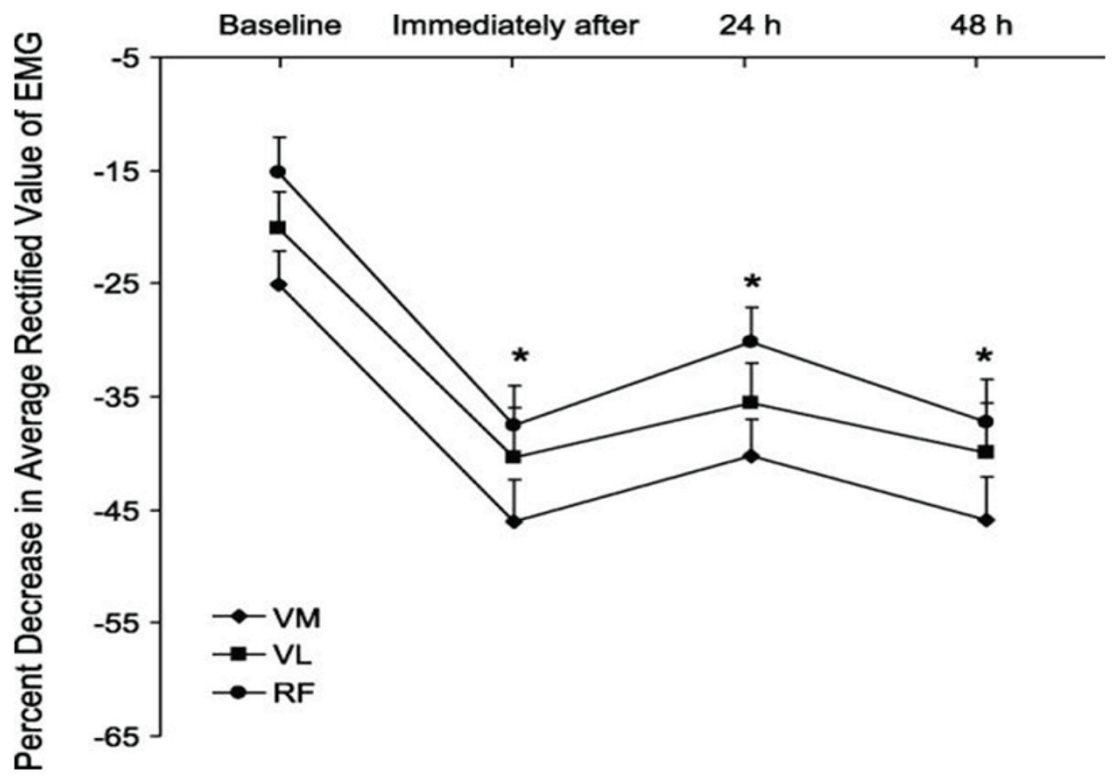

Figure 6 Percent decrease in the ARV of the EMG (mean \pm SE, $n=10$ subjects) over time for the vastus medialis (VM), rectus femoris (RF), and vastus lateralis (VL) muscle during sustained contractions performed at $50 \% \mathrm{MVC}$, recorded before the eccentric exercise (baseline), immediately after, and 24 and $48 \mathrm{~h}$ after the eccentric exercise; $* \mathrm{P}<0.05$. $* \mathrm{PG} 0.05$.

expected to have an effect on reflex activity of the muscle. In the second study the effect of dynamic exercise induced fatigue on postural control were investigated.

\section{Study II}

Nine healthy recreationally active men participated in this study. Surface electromyographic (EMG) signals were recorded from the knee extensor (VM, $\mathrm{RF}, \mathrm{VL}$ ) and flexor muscles (BF, ST) of the right leg during full body perturbations performed at baseline and immediately following high intensity exercise performed on a bicycle ergometer. In each condition, participants stood on a moveable platform during which 16 randomized postural perturbations (eight repetitions of two perturbation types: $8 \mathrm{~cm}$ forward slides, $8 \mathrm{~cm}$ backward slides) with varying inter-perturbation time intervals were performed over a period of 2-3 min. Maximal voluntary knee extension force was measured before and after the high intensity exercise protocol to confirm the presence of fatigue. 


\section{Results}

Immediately after exercise, the maximal force significantly decreased for knee extensors and flexors. There was a decrease in EMG amplitude during the anterior slide perturbations for the VL, RF, BF, and ST muscles compared with the pre-exercise condition (Figure 7).

Moreover the EMG onset was significantly delayed during the anterior slide for the $\mathrm{VM}, \mathrm{VL}$, and $\mathrm{BF}$ in the post exercise condition with respect to the pre-exercise condition but not for the RF and ST muscles (Figure 8).

Moreover, a significant correlation $(\mathrm{R} 2=0.53$; Figure 9$)$ was identified between the percent reduction of knee extension MVC and the percent change in onset time of the knee extensors post exercise but not for the flexors (Figure 9).

\section{Discussion}

This study shows that high intensity dynamic exercise of the knee muscles impairs the response to fast, functionally relevant, full body perturbations, suggesting that exercise-induced muscle fatigue may compromise dynamic knee joint stability which commonly occur during sporting activities. Impaired neuromuscular responses to postural perturbations may place the fatigued individual at a greater risk for musculoskeletal injury and therefore steps should be taken during conditioning and rehabilitation of athletes to help
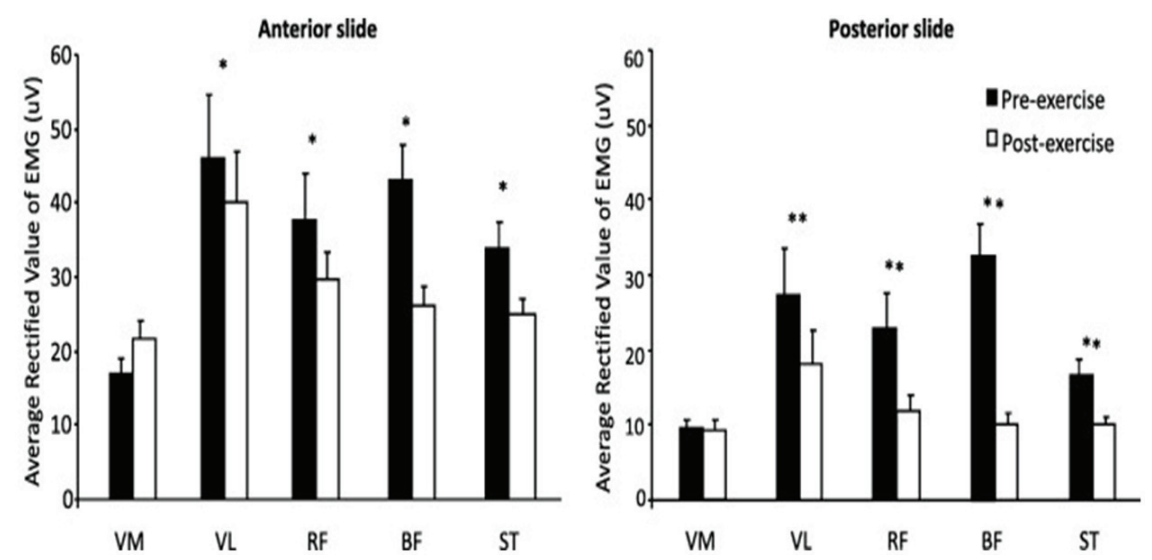

Figure 7 Mean $\pm \mathrm{SE}$ of the average rectified value (ARV) of the EMG recorded from the vastus medialis (VM), vastus lateralis (VL), rectus femoris (RF), biceps femoris (BF) and semitendinosus (ST) muscles during anterior and posterior slide perturbations at baseline and following high intensity exercise performed on a bicycle ergometer. ${ }^{*} \mathrm{P}<0.05$, ${ }^{*} * \mathrm{P}<0.0001$ 

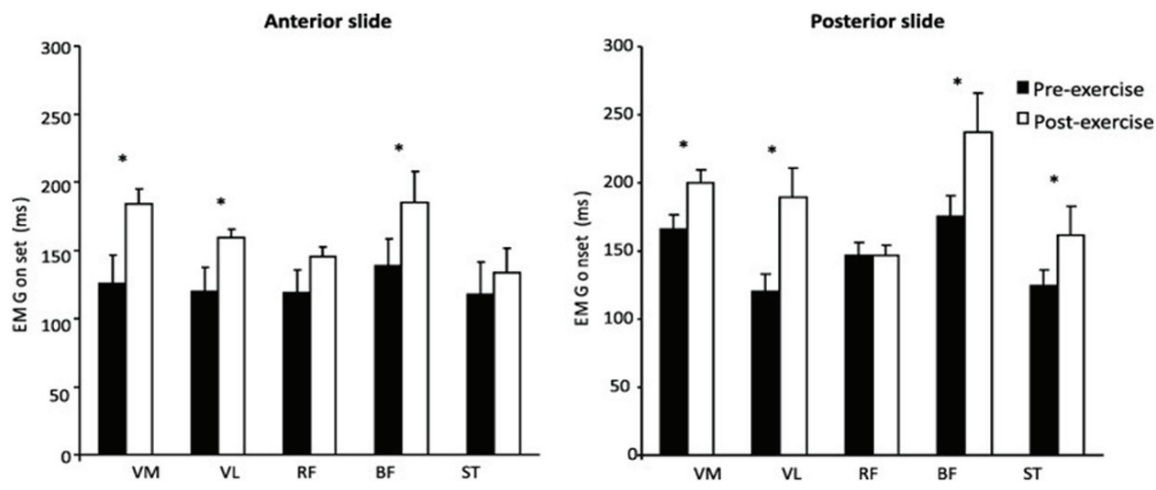

Figure 8 Mean \pm SE of the EMG onset recorded from the vastus medialis (VM), vastus lateralis (VL), rectus femoris (RF), biceps femoris (BF) and semitendinosus (ST) muscles during anterior and posterior slide perturbations at baseline and following high intensity exercise performed on a bicycle ergometer. ${ }^{*} \mathrm{P}<0.05$

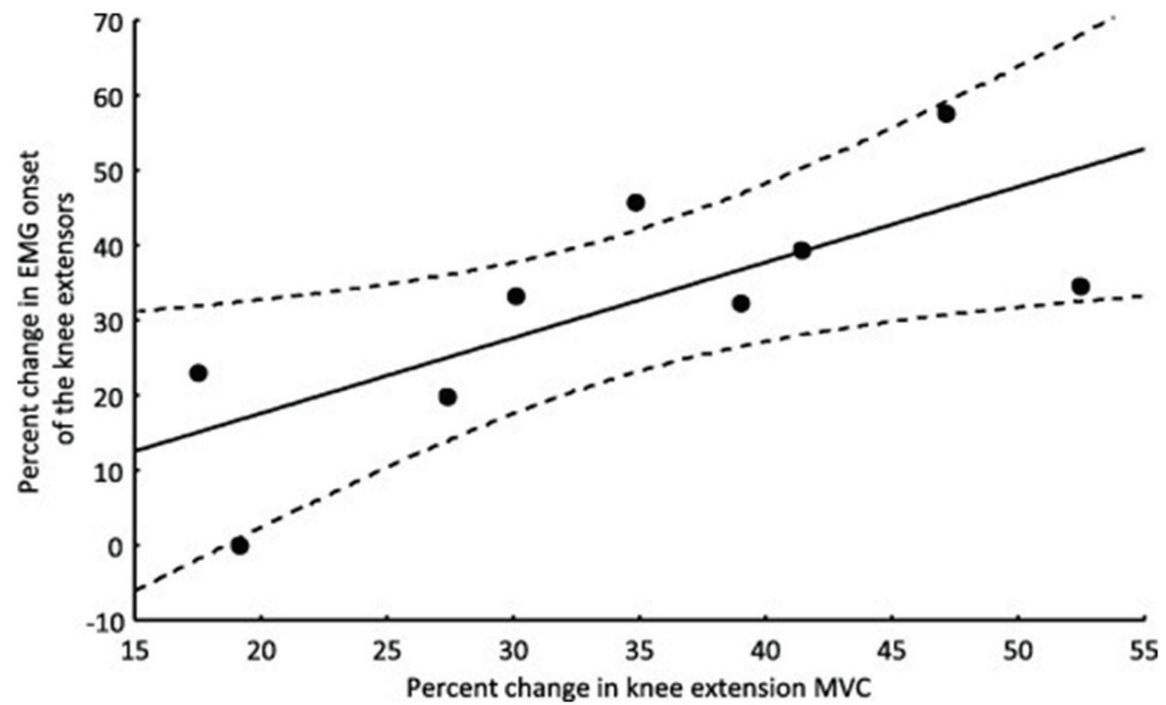

Figure 9 Scatter plot with $95 \%$ confidence interval showing a significant correlation $(\mathrm{R} 2=0.53 ; \mathrm{P}<0.05)$ between the percent reduction of knee extension MVC and the percent change in onset time of the knee extensors post exercise 
prevent muscle fatigue. It is likely that sports injuries to the knee joint occur during a time interval shorter than the first half of ground contact in injury prone tasks, which would be less than $75-100 \mathrm{~ms}$ after initial contact. A delay of reactive activation of the hamstrings and quadriceps muscle by $\sim 40 \mathrm{~ms}$, as shown in this study, may leave the knee joint vulnerable in the fatigued state. Minimizing the fatigue induced delay of muscle activity may be an important approach to reduce injury risk in perturbed as well as unperturbed jump landings or change in direction tasks.

\section{Study III}

For this study eighteen healthy sedentary men, with no history of lower limb disorders, participated and were assigned to either a 6-week endurance training program $(n=10)$ or a control group (no intervention; $n=8)$. At baseline and following 6 weeks endurance training, maximal voluntary contractions (MVC), power output and anterior-posterior center of pressure (COP) sway was analyzed during rapid full body perturbations performed before and after the high intensity exercise protocol. Endurance training was performed on a bicycle ergometer, and the exercise intensity was prescribed based on the percentage of the heart rate reserve (HRR) calculated with the Karvonen method. Maximal power output was determined using the ramping test to evaluate the performance of the participants. Knee extension and flexion MVC were measured during isometric contractions before and after the exercise protocol. Moreover, Muscle fibre conduction velocity (MFCV) of the VM and VL muscles was measured during $20 \%$ of MVC, which was sustained for $30 \mathrm{~s}$. furthermore, postural perturbations were produced using a computer controlled movable platform and changes in the COP were assessed from the onset of platform movement until $500 \mathrm{~ms}$ after initiation of platform movement (Figure 10).

\section{Results}

For the training group, the power output measured at week 7 was significantly greater than baseline $(\mathrm{P}<0.001)$. Before the training program, the MVC decreased from the pre fatigue condition to the post fatigue condition by $33 \pm 13 \%$ for knee extensors (pre: $581.7 \pm 168.9 \mathrm{~N}$; post: $441.7 \pm 143.3 \mathrm{~N}$, $\mathrm{P}<0.001$ ) and by $24 \pm 18 \%$ for knee flexors (pre: $133.2 \pm 25.6 \mathrm{~N}$; post: 109.2 $\pm 25.1 \mathrm{~N}, \mathrm{P}<0.001$ ), respectively, in the individuals that were assigned to the training group. Following the training program, the maximal knee extension 


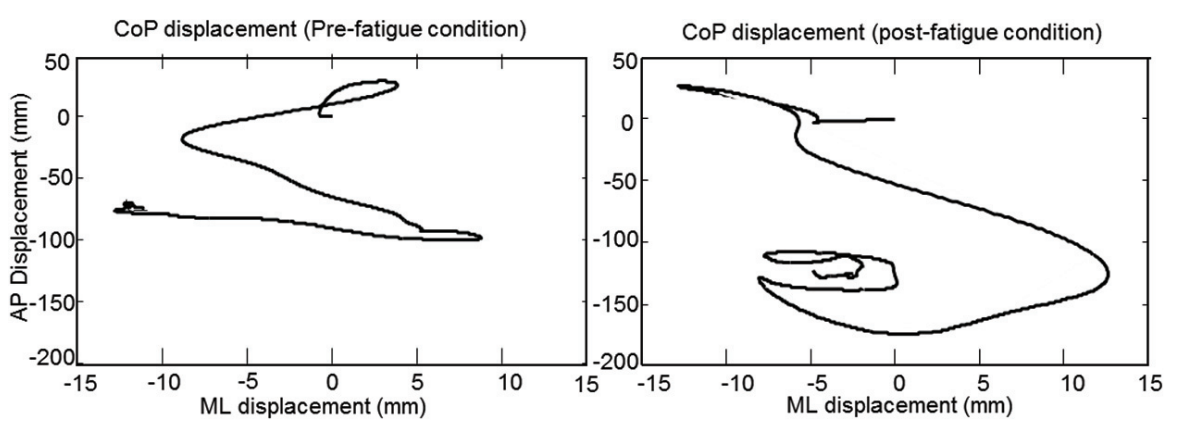

Figure 10 Representative COP signals recorded for $500 \mathrm{~ms}$ after initiation of platform movement during the pre and post fatigue condition from one representative subject

force from the pre fatigue condition to post fatigue condition was reduced by $15 \pm 11 \%$ (pre: $680 \pm 173.2 \mathrm{~N}$; post: $602 \pm 174.1 \mathrm{~N}, \mathrm{P}<0.05$ ). However, the knee flexion MVC was not significantly altered by the dynamic exercise (pre: $166.4 \pm 29.6 \mathrm{~N}$; post: $134.6 \pm 22.1 \mathrm{~N} ; \mathrm{P}>0.05$ ). The fatiguing exercise induced a reduction in MFCV at both the pre and post sessions for the training group $(\mathrm{P}<0.001)$. However, the rate of reduction of MFCV at the post training session was smaller than at the pre training session $(\mathrm{P}<0.05)$.

Moreover, at baseline, the fatiguing exercise induced an increase in the anterior-posterior COP sway during the perturbations for both the training and control group $(\mathrm{P}<0.05)$. For the training group the COP sway during the rapid postural perturbation was not altered by the fatiguing protocol when assessed at week $7(\mathrm{P}>0.05)$.

\section{Discussion}

A significant decrease in MVC was observed indicating that the fatigue protocol used in this study was sufficient to reduce the ability of the muscle to generate force. A significant increase in COP sway in the anterior-posterior direction was also observed in a fatigued state. Following six weeks of endurance training, muscle power output increased and subjects were able to continue a fatiguing exercise longer than in the baseline condition, indicating a delay in the onset of muscle fatigue. In addition, subjects were able to better maintain balance in response to unexpected perturbations in the presence of fatigue. The present study shows that poor physical capacity and conditioning leads to greater force decline following exercise. Athletes with such a condition may reach the state of fatigue earlier and such impairments might affect their balance during competition leading to injury. Moreover, it is important for the 
rehabilitation of the injured athletes that they should improve their balance along with endurance and aerobic capacity before return to active sport.

\section{Study IV}

Eighteen healthy sedentary men were participated in this study. Maximal voluntary knee extension isometric contractions (MVC) and knee extension MVCs with superimposed electrical stimulation of the femoral nerve were measured before and after the fatiguing exercise at baseline and following 6 weeks endurance training. Moreover muscle fiber conduction velocity of the vasti muscles (measured during sustained isometric knee extension at $30 \%$ MVC) was measured before and immediately following the fatiguing exercise. To quantify central activation failure during each MVC, the central activation ratio (CAR) was calculated as the MVC divided by the total force (stimulated + voluntary force).

\section{Results}

Knee extensor MVC increased by $15 \pm 8 \%$ ( $\mathrm{P}<0.001)$ on week 7 compared to baseline for the training group (Pre: $581.7 \pm 168.9 \mathrm{~N}$; Post: $680.7 \pm 173.2 \mathrm{~N}$ ). For the control group, the maximal force produced by the knee extensors (Pre: $318.1 \pm 93.9 \mathrm{~N}$; Post: $302.5 \pm 86.2 \mathrm{~N}$ ) was not significantly different from baseline $(\mathrm{P}>0.05$, Figure 11).

The power output increased by $14.5 \%(\mathrm{P}<0.001)$ for the training group (Pre: $257.5 \pm 24.7 \mathrm{~W}$; Post: $295.3 \pm 30.8 \mathrm{~W}$ ) whereas it remained unchanged for the control group (Pre: $263.1 \pm 42.7 \mathrm{~W}$; Post: $265 \pm 44.6 \mathrm{~W})(\mathrm{P}>0.05$, Figure 12).

The rate of reduction in muscle fiber conduction velocity in post training condition was lower than pre training condition (Figure 13).

Moreover, there is a reduction in CAR in post fatigue condition at both pre and post training; however, central activation ratio in post training condition was increased compare with pre-training condition (Figure 14).

\section{Discussion}

Six weeks of progressive endurance training on a cycle ergometer improved power output, MVC, and CAR of the quadriceps muscle. Furthermore, the rate of reduction in MFCV of the vasti muscles during sustained isometric knee extension contractions was reduced following training. This study shows 


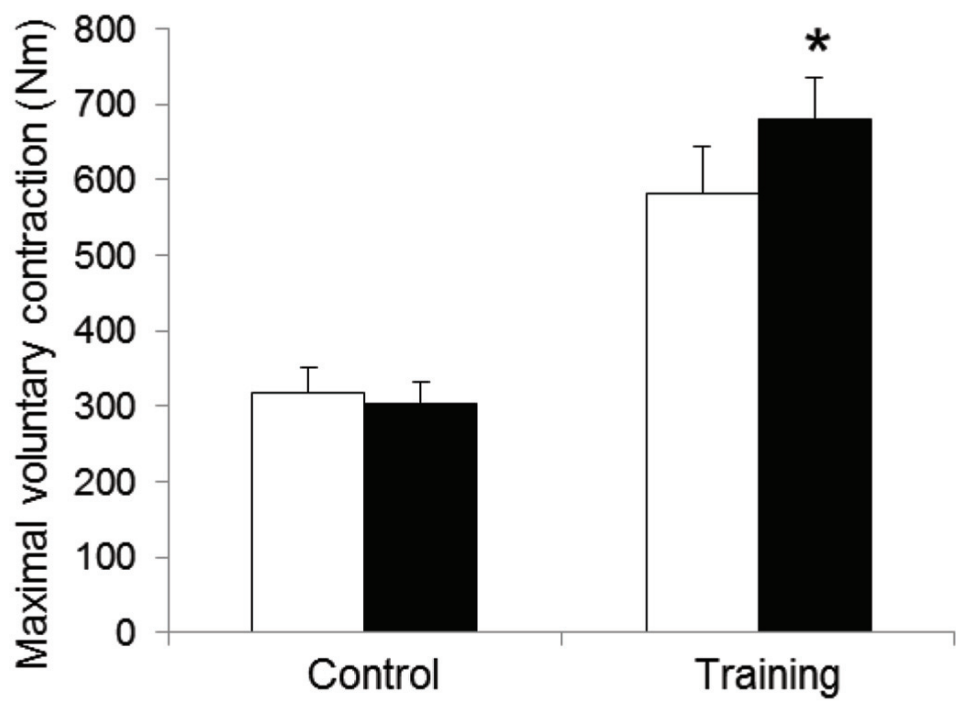

$\square$ week 0

- week 7

Figure 11 Mean \pm SE of the maximal voluntary contraction (MVC) recorded at baseline (week 0) and (week 7) for both training and control groups. *: $P<0.001$

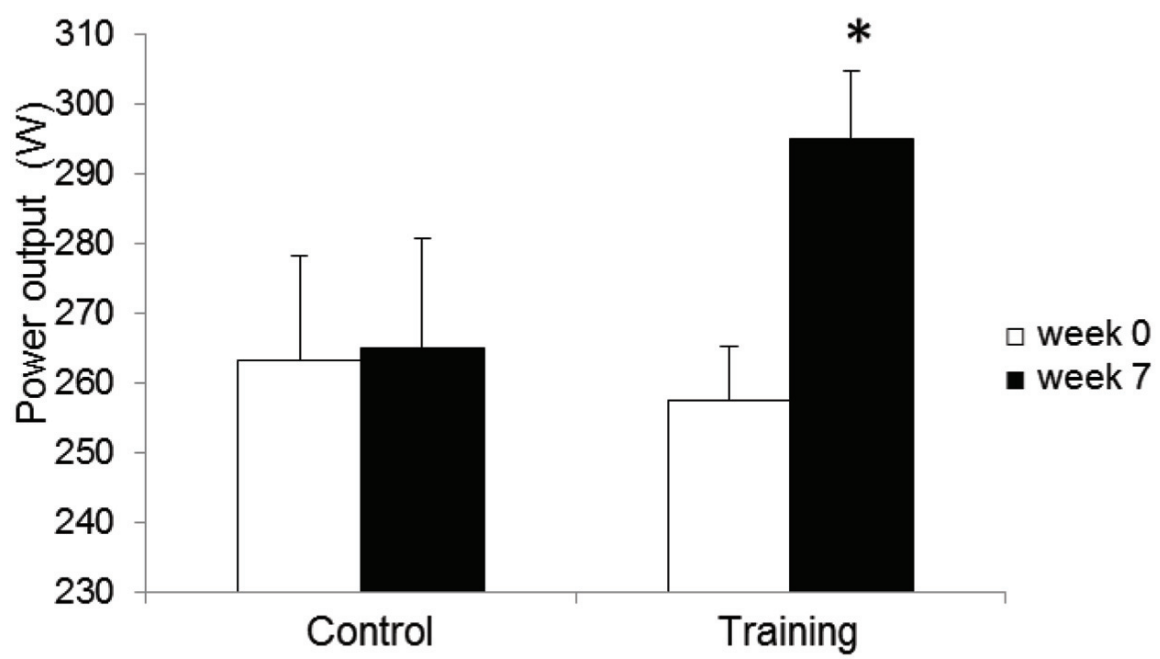

Figure 12 Mean \pm SE of the power output measured at baseline (week 0) and (week 7) for both training and control groups. *: $P<0.05$ 
22 Summary of the Studies

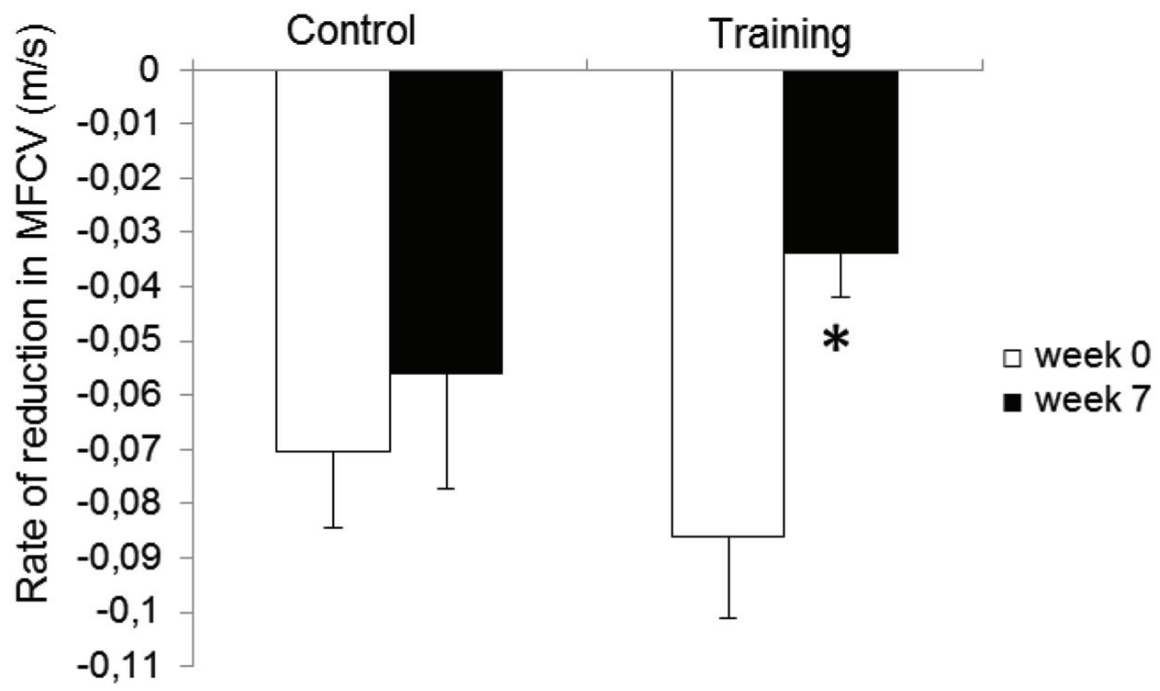

Figure 13 Mean \pm SE of the rate of reduction in muscle fiber conduction velocity (MFCV) measured during $20 \%$ of MVC sustained for $30 \mathrm{~s}$. Data were collected at baseline (week 0) and (week 7) for both training and control groups. *: $P<0.05$

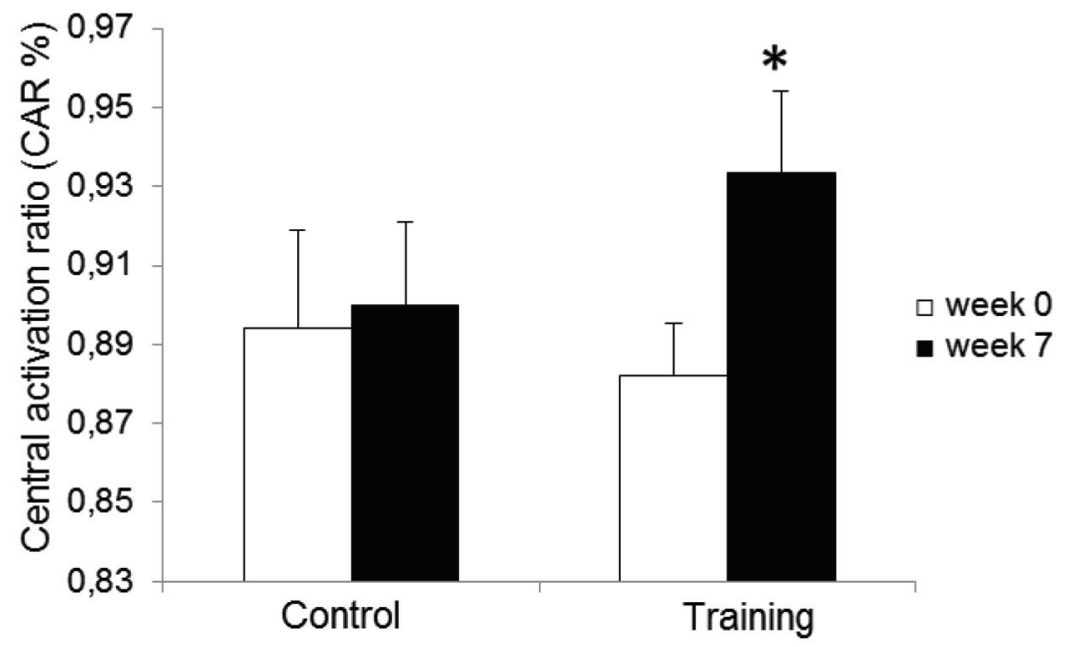

Figure 14 Mean $\pm \mathrm{SE}$ of the percent change in central activation ratio (CAR) assessed at baseline (week 0 ) and (week 7) for both training and control groups. *: $P<0.05$ 
specific training-induced adjustments in central and peripheral components of high intensity exercise induced muscle fatigue. Relative to a control group, the group participating in 6 weeks of progressive endurance training showed a greater ability to resist high intensity fatiguing exercise which is attributed to adaptations at both peripheral and central components of the nervous system. This knowledge is relevant for sports science and may assist in the development of training programs to enhance resistance to fatigue. 



\section{General Discussion and Conclusions}

Skeletal muscle fatigue is an inevitable part of high intensity exercise and is associated with reduced power output and work capacity of the skeletal muscle. The factors that could potentially cause a decrease in maximal force after fatigue include both central and peripheral components of fatigue. Peripheral skeletal muscle fatigue is usually defined as a decrease in the capacity of the skeletal muscle to generate force because of action potential failure, excitation contraction coupling failure, or impairment of cross bridge cycling, in the presence of unchanged or increasing neural drive. Central fatigue results from suboptimal facilitation from the motor cortex decreased facilitation from muscle spindles, increased inhibition from group III and IV afferents, and desensitization of the motoneurons.

Fatigue-induced impairments in neuromuscular control may adversely alter joint proprioception and are believed to be a potential cause for the increased injury rates during the latter stages of athletic competition particularly during sudden deceleration, landing and pivoting maneuvers. The work performed in this thesis demonstrated alterations in activity for both the quadriceps and hamstring muscles and increases in the anterior-posterior COP sway in response to fast, functionally relevant, full body perturbations in the presence of fatigue. The effects shown in these studies, such as impaired neuromuscular responses and increased postural sway in response to fast, full body perturbations may place the fatigued individual at a greater risk for musculoskeletal injury in real-life sports situations such as games or extended training sessions. Therefore, steps should be taken during conditioning and rehabilitation of athletes to help prevent muscle fatigue. Moreover, the effects of endurance training on postural control following fatiguing exercise were investigated within this thesis.

Following training, an improved postural control during full body perturbations performed was observed immediately after high-intensity exercise. This may be explained by several mechanisms. It may partly relate to the ability to recruit an additional number of motor units in exercising muscles. Moreover, endurance training leads to decreased blood lactate accumulation 
at a given submaximal workload. Our training protocol significantly increased muscle power output and subjects were able to continue the fatiguing exercise longer than the baseline condition, indicating a delay in the onset of muscle fatigue. The ability to resist fatigue (i.e., sustain a high power output or smaller decrement in force) is probably related to the contractile properties of endurance trained skeletal muscle. Increased voluntary activation of the quadriceps muscle and changes in muscle fiber conduction velocity rate of reduction following training indicates several adaptations in the muscle. These adaptations may be explained by changes in the recruitment thresholds, discharge patterns of neurons and lower co-activation in the trained muscle.

The results of this work suggest that it is important, in particular, for the rehabilitation of injured athletes to improve their balance along with endurance and aerobic capacity before return to active sport. Moreover, this study shows specific training-induced adjustments of central and peripheral components of high intensity exercise induced muscle fatigue. This approach improves our understanding of the mechanisms of human muscle fatigue by simultaneously assessing function at the various levels along the pathway of force production. This knowledge is relevant for sports science and may assist in the development of training programs to enhance resistance to fatigue. Moreover, in a clinical setting the quantification of contributing components to fatigue during maximal effort can be of implications as many neuromuscular patient groups complain about fatigue. 


\section{References}

[1] Allen D. G., Lamb G. D, and Westerblad H. Skeletal Muscle Fatigue: Cellular Mechanisms Physiol Rev 2008;88: 287-332

[2] Bailey SP, Davis JM, Ahlborn EN. Neuroendocrine and substrate responses to altered brain 5-HT activity during prolonged exercise to fatigue. J Appl Physiol 1993;74:3006-12

[3] Barrack RL, Skinner HB, Brunet ME, Cook SD. Joint laxity and proprioception in the knee. Physician Sportsmed 1983;1 1(6): 130-135

[4] Beaumont, E \& Gradiner, P.F. Endurance training alters the biophysical properties of the hindlimb motoneurons in rats Muscle \& nerve 2003;27:228-236

[5] Becker EL, Butterfield WJH, Harwey MC, Gehee A, Heptinstall RH \& Thomas L (eds) (1986) International dictionary of medicine and biology. A Wiley Medical Publication. John Wiley \& Sons. New York. USA

[6] Berg KO, Wood-Dauphinee S, Williams JI \& Gayton D. Measuring balance in the elderly: preliminary development of an instrument. Physiotherapy Canada 1989;41: 304- 311

[7] Blomstrand E, Hassmen P, Newsholme EA. Effect of branched-chain amino acid supplementation on mental performance. Acta Physiol Scand 1991;143:225-226

[8] Bonen A, Baker SK, Hatta H. Lactate transport and lactate transporters in skeletal muscle. Can J Appl Physiol 1997; 22: 531-52

[9] Broman H, Bilotto G, De Luca CJ Myoelectric signal conduction velocity and spectral parameters: influence of force and time. J Appl Physiol 1985;58:1428-1437

[10] Carolan, B. \& Cafarelli, E. Adaptations in coactivation after isometric resistance training, journal of applied physiology 1992;3:911-917

[11] Conlay LA, Sabounjian LA, Wurtman RJ. Exercise and neuromodulators: choline and acetylcholine in marathon runners. Int J Sports Med 1992;1:141-2

[12] De Luca, C,J., Le Fever, R.S., McCue, M.P. \& xendakis, A.P. Behavior of human motor units in different muscles during linearly varying contractions, the journal of physiology 1982;329: 113-128 
[13] Enoka RM, Stuart DG Neurobiology of muscle fatigue. J Appl Physiol 1992;72:1631-1648

[14] Era P, Schroll M, Ytting H, Gause-Nilsson I, Heikkinen E \& Steen B Postural balance and its sensory - motor correlates in 75-year-old men and women: A cross-national comparative study. J Gerontol: Medical Sciences 1996 51A: M53-M63

[15] Favier RJ, Constable SH, Chen M, et al. Endurance exercise training reduces lactate production. J Appl Physiol 1986; 61: 885-9

[16] Feagin JA, Lambert KL, Cunningham RR, et al. Consideration of the anterior cruciate ligament injury in skiing. Clin Orthop Rel Res 1987:21613-18

[17] Fitts RH. Cellular mechanisms of muscle fatigue. Physiol Rev 1994;74:49-94

[18] Fitts RH. Muscle fatigue: the cellular aspects. Am J Sports Med. 1996;24(6)

[19] Gandevia S. Spinal and supraspinal factors in human muscle fatigue. Physiol Rev 2001;814:1725-89

[20] Graham TE, Saltin B. Estimation of the mitochondrial redox state in human skeletal muscle during exercise. J Appl Physiol 1989; 66:561-6

[21] Green HJ, Chin ER, Ball-Burnett M, et al. Increases in human skeletal muscle $\mathrm{Na}+\mathrm{K}+$-ATPase concentration with short-term training. Am $\mathbf{J}$ Physiol 1993;264: C1538-41

[22] Gribble PA, Hertel J. Effect of lower-extremity muscle fatigue on postural control. Arch Phys Med Rehabil 2004b;85(4):589-92

[23] Guezennec CY, Abdelmalki A, Serrurier B, et al. Effects of prolonged exercise on brain ammonia and amino acids. Int J Sports Med 1998;19:323-7

[24] Hakkinen K, Komi PV. Electromyographic and mechanical characteristics of human muscle during fatigue under voluntary and reflex conditions. Electroencephalogr Clin Neurophysiol 1983;55: 436-44

[25] Harms SJ, Hickson RC. Skeletalmuscle mitochondria andmyoglobin, endurance, and intensity of training. J Appl Physiol 1983; 54: 798-802

[26] Hawkins R, Fuller C. A. prospective epidemiological study of injuries in four English professional football clubs. Br J Sports Med. 1999;33(3):196-203

[27] Hedayatpour N, Hassanlouei H, Arendt-Nielsen L, Kersting UG, Falla D. Delayedonset muscle soreness alters the response to postural perturbations. Med Sci Sports Exerc 2011;43(6):1010-6 
[28] Inoue K, Yamazaki H, Manabe Y, et al. Transforming growth factor-beta activated during exercise in brain depresses spontaneous motor activity of animals. Relevance to central fatigue. Brain Res 1999;846:145-53

[29] Johansson JO \& Jarnlo GB (1991) Balance training in 70-year-old women. Physiotherapy Theory and Practise 7: 121-125

[30] Kiens B, Essen-Gustavsson B, Christensen NJ, et al. Skeletal muscle substrate utilisation during sub-maximal exercise in man: effect of endurance training. J Physiol 1993; 469: 459-78

[31] Lattanzio P-J, Petrella RJ, Sproule JR, Fowler PJ. Effects of fatigue on knee proprioception. Clin J Sports Med 1997;7:22- 27

[32] Lattier, G., Millet, G.Y., maffiuletti, N.A., Babault, N. \& lepers, R., Neuromuscular differences between endurance trained, power trained, and sedentary subjects. journal of strength and conditioning research / national strength \& conditioning association 2003;17:514-521

[33] Masuda T, Miyano H, Sadoyama T. A surface electrode array for detecting action potential trains of single motor units. Electroencephalogr Clin Neurophysiol 1985;60(5):435-43

[34] McCullagh KJA, Poole RC, Halestrap AP, et al. Role of the lactate transporter (MCT1) in skeletal muscles. Am J Physiol 1996; 271 (34): $143-50$

[35] Miura K, Ishibashi Y, Tsuda E, Okamura Y, Otsuka H, Toh S. The effect of local and general fatigue on knee proprioception. Arthroscopy. 2004;20(4):414-8

[36] Myer GD, Ford KR, Brent JL, Hewett TE. The effects of plyometric vs. dynamic stabilization and balance training on power, balance, and landing force in female athletes. J Strength Cond Res 2006;20: 345-53

[37] Myer GD, Ford KR, McLean SG. The effects of plyometric versus dynamic stabilization and balance training on lower extremity biomechanics. Am J Sports Med 2006;34: 445-55

[38] Nashner LM Analysis of movement control in man using the movable platform. In: Motor Control Mechanism in Health and Disease, Ed. JE Desmedt, Raven Press, New York. 1983 pp. 607-619

[39] Paasuke, M., Ereline, J. \& Gapeyeva, H. twitch contractile properties of plantar flexor muscles in power and endurance trained athletes. Europeans journal of applied physiology and occupational physiology 1999; 80:448-451

[40] Pilegaard H, Bangsbo J, Richter EA, et al. Lactate transport studied in sarcolemmal giant vesicles from human muscle biopsies: relation to training status. J Appl Physiol 1994; 77:1858-62 
[41] Prochazka A \& Wand P Tendon organ discharge during voluntary movements in cats. J Physiol (Lond) 1980;303: 385-390

[42] Rozzi, S.L. P. Yuktanandana, D.M. Pincivero, S.M. Lephart, Role of fatigue on proprioception and neuromuscular control, in: S.M. Lephart, F.H. Fu (Eds.), Proprioception and Neuromuscular Control in Joint Stability, Human Kinetics, Champaign, IL 2000, pp. 375-383

[43] Sakai H, Tanaka S, Kurosawa H, Masujima A. The effect of exercise on anterior knee laxity in female basketball players. Int J Sports Med. 1992; 13:552-554

[44] Schantz PG, Sjoberg B, Svedenhag J. Malate-aspartate and alphaglycerophosphate shuttle enzyme levels in human skeletal muscle: methodological considerations and effect of endurance training. Acta Physiol Scand 1986; 128: 397-407

[45] Skinner HB, Wyatt MP, Hodgdon JA, Conard DW, Barrack RL. Effect of fatigue on joint position sense of the knee. J Orthop Res 1986;4: 112-118

[46] Smith LL. Cytokine hypothesis of overtraining: a physiological adaptation to excessive stress. Med Sci Sports Exerc 2000;32:317-31

[47] Smith LL. Acute inflammation: the underlying mechanism in delayed onset muscle soreness? Med Sci Sports Exerc 1991;23(5): 542-51

[48] Spina RJ, Chi MM, HopkinsMG, et al.Mitochondrial enzymes increase in muscle in response to 710 days of cycle exercise. J Appl Physiol 1996; 80: $2250-4$

[49] Spirduso WW. Physical Dimensions of Aging. Human Kinetics 1995. Champaign. Illinois. USA

[50] Surenkok, O, Kin-Isler, A, Aytar, A, Gültekin, Z. Effect of trunk-muscle fatigue and lactic acid accumulation on balance in healthy subjects. J. Sport Rehabil. 2008;17:380-386

[51] Taylor AD, Brooks R, Smith P, et al. Myoelectric evidence of peripheral muscle fatigue during exercise in severe hypoxia: some references to m. vastus lateralis myosin heavy chain composition. Eur J Appl Physiol 1997;75:151-9

[52] Tuggy ML, Ong R. Injury risk factors among telemark skiers. Am J Sports Med 2000;28:83-89

[53] Voight ML, Hardin JA, Blackburn TA, Tippett S, Canner GC. The effects of muscle fatigue on and the relationship of arm dominance to shoulder proprioception. J Orthop Sports Phys Ther 1996;23(6):348-52

[54] Wenger HA, Bell GJ. The interactions of intensity, frequency and duration of exercise training in altering cardiorespiratory fitness. Sports Med 1986; 3: $346-56$ 
[55] Wilson WM, Maughan RJ. Evidence for a possible role of 5hydroxytryptamine in the genesis of fatigue in man: administration of paroxetine, a 5-HT re-uptake inhibitor, reduces the capacity to perform prolonged exercise. Exp Physiol 1992;77:921-4

[56] Wojtys, E.M.Wylie B.B, Huston L.J., The effects of muscular fatigue on neuromuscular function and anterior translation in healthy knees. Am J Sports Med 1996;2 (5):615-621.

[57] Zempher ED. Injury rates in a national sample of college football teams: A 2 year retrospective study. Physician Sports Med 1989;11:104-113

[58] Ziv I, Avraham M, Michaelov Y, et al. Enhanced fatigue during motor performance in patients with Parkinson's disease. Neurology $1998 ; 51: 1583-6$ 



\section{About the Author}

Hamidollah Hassanlouei was born in Makoo, Iran in 1977. He graduated in exercise physiology from Shahid Beheshty University, Tehran, Iran in 2003. $\mathrm{He}$ received his Ph.D. in motor control, from Aalborg University, Denmark, for his work at the Center for Sensory-Motor Interaction (SMI). He is currently working as a post-doctoral fellow on projects in the field of training and motor control, and published several papers in peer reviewed journals.

Skeletal muscle fatigue is an inevitable part of any exercise and is associated with impairments in joint proprioception, joint position sense and joint laxity.

The objective of this thesis was to investigate the effect of musculoskeletal fatigue on postural control and the effect of an endurance training intervention on central and peripheral components of fatigue. The muscles around the knee play an important role in explosive and powerful performance of the leg during daily life and sporting activities. However, fatigue- induced impairments in muscle function may reduce the ability of the muscles around the knee to stabilize the knee joint. This may expose structures of the knee to abnormal loading during exercise. Training has been extensively shown to lead to resistance to fatigue however the effects of endurance training on postural control as well as central and peripheral components of exercise induced fatigue is unknown. In this thesis, four studies were performed. First, the effects of eccentric exercise and delayed onset muscle soreness of the knee muscle on postural control were investigated in healthy subjects. In this study muscle activation around the knee were examined. In a second study, the effects of dynamic fatiguing exercise on postural control were investigated and muscle activation responses following high intensity dynamic exercise were investigated. In third study, the effects of 6 weeks progressive endurance training on postural control following fatiguing exercise were examined. In the fourth and final study, the effects of training on central and peripheral components of fatigue following high intensity dynamic exercise were investigated. The results showed lower electromyography (EMG) amplitude and delayedEMGonset following skeletal muscle fatigue induced by eccentric and 


\section{About the Author}

dynamic exercise. However, following 6 weeks endurance training subjects increased their resistance to fatigue, i.e., were able to sustain a high power output, showed increased knee maximum muscle force and smaller decrement in force following exercise, and a smaller reduction in muscle fiber conduction velocity during a sustained contraction. Moreover following training, subjects improved postural stability during unexpected perturbations in the presence of fatigue. Training induced adaptations were shown to occur at both peripheral and central components of the nervous system. 